\title{
PENGARUH PENAMBAHAN BUBUR DAUN SINGKONG (Manihot esculenta) TERHADAP KARAKTERISTIK STIK YANG DIHASILKAN
}

\author{
Nofi Mustika Sari ${ }^{(1)}$, dan Retti Ninsix, S.Tp., MP ${ }^{(2)}$ \\ (1) Alumni Teknologi Pangan Faperta UNISI

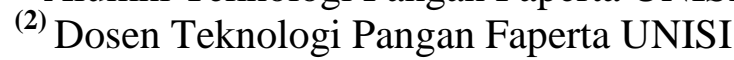

\begin{abstract}
Abstrak
Penelitian ini bertujuan untuk mengetahui pengaruh penambahan bubur daun singkong terhadap karakteristik stik yang dihasilkan. Metode yang digunakan dalam penelitian ini adalah metode experimen langsung yakni mengadakan pengamatan langsung terhadap objek penelitian, dengan berat bahan yang digunakan adalah 250 gram tepung terigu dan 50 gram tepung kacang hijau. Rancangan yang digunakan adalah rancangan acak lengkap (RAL) dengan 4 perlakuan, yaitu A : Bubur daun singkong $10 \%$ perberat bahan, B : Bubur daun singkong $20 \%$ perberat bahan, C : Bubur daun singkong 30\% perberat bahan, dan D : Bubur daun singkong 40\% perberat bahan. Perlakuan ini diulang sebanyak 4 perlakuan dengan 3 kali ulangan sehingga diperoleh pola perlakuan 4 x 3 dengan 12 unit percobaan. Hasil terbaik pada stik yang dihasilkan yaitu perlakuan A dengan penambahan bubur daun singkong sebanyak $10 \%$ per berat tepung kacang hijau dan tepung terigu, yang mempunyai nilai rasa 3,7, warna 4,25, aroma 3,45, tekstur ,4,05, kandungan air $8,25 \%$, kandungan protein $8,25 \%$ dan kandungan pati $24,60 \%$.
\end{abstract}

Kata Kunci : Stik, daun singkong, kacang hijau

\section{PENDAHULUAN}

Tanaman Singkong (Manihot Esculenta) merupakan tanaman yang memilki kandungan gizi yang cukup lengkap. Kandungan zat dalam tanaman singkong ialah karbohidrat, fosfor, kalsium, vitamin $\mathrm{C}$, protein, zat besi dan vitamin B1. Seiring dengan kemajuan ilmu pengetahuan dan teknologi, pemanfaatan tanaman singkong berkembang sebagai bahan baku industri pangan dan sebagai pengobatan herbal. Secara umum, singkong merupakan jenis tanaman yang mempunyai potensi untuk dikembangkan sebagai tanaman obat dan bahan baku industri pangan, (Salim, 2011).
Daun singkong merupakan limbah dari sistem produksi pertanian singkong terutama pada daerah industri tapioka. Ketersediaan daun singkong terus meningkat dengan semakin meluasnya areal penanaman dan produktivitas tanaman singkong. Hampir 10-40\% dari tanaman singkong terdiri atas daun. Produksi daun singkong segar adalah 1040 ton/ha/tahun atau 2,3 ton berat kering/ha/tahun (Sukria dan Rantan, 2009). Luas area penanaman tanaman singkong pada tahun 2013 seluas 16.163 ha dengan produktivitas umbi singkong segar sebanyak 43,028 ton/ha dan total produksi sebanyak 695.460 ton (BPS, 2013). 
Daun singkong pada umumnya memiliki kandungan protein berkisar antara 20-27\% dari bahan kering (Marhaeniyanto, 2007). Daun singkong merupakan limbah dari sistem produksi pertanian singkong terutama pada daerah industri tapioka. Daun singkong selain sebagai pakan ternak juga dapat diolah menjadi produk pangan yaitu, sayur, kerupuk, tempe dan dendeng.

Stik merupakan salah satu makanan cemilan ringan yang sangat digemari oleh anak-anak maupun orang dewasa. Berbagai macam stik sering kita jumpai di pasaran misalnya stik kentang, keju, tempe, ubi dan talas. Dikarenakan stik merupakan makanan yang digemari oleh setiap orang oleh karena itu pencampuan daun singkong yang akan tinggi nutrisi terutama protein kedalam proses pembuatan stik bisa menjadi salah satu alternatif pangan yang akan tinggi nutrisi protein. Selain daun singkong, kacang hijau merupakan pangan yang akan tinggi protein.

Penelitian (Amrullah, 2015) yang berjudul Mutu Organoleptik dan Kimiawi Stik Rumput Laut Kappaphycus Alvarezii dengan Fortifikasi Tepung Udang Rebon (Mysis Sp.) Hasil penelitian utama tentang formulasi terpilih dalam pembuatan stik rumput laut yang ditambahkan tepung udang rebon adalah penambahan tepung udang rebon sebanyak $7,5 \%$ (Formulasi B), dengan kriteria nilai organoleptik kenampakan utuh, rapi, bersih, warna kekuningan agak pucat nilai 7,12, aroma udang dan rumput laut kurang nilai 7,40, rasa udang dan rumput laut kurang kuat nilai 8,40 , dan tekstur udang kering dan renyah nilai 8,32. Hasil karakteristik kimiawi produk stik rumput laut terpilih (penambahan tepung udang rebon 7,5\%) memiliki Kadar air 1,26\%, kadar abu 19,84\%, kadar protein 18,33\%, kadar lemak $36,40 \%$, dan kadar karbohidrat $24,17 \%$.

Alternatif bahan baku yang dapat digunakan dalam pengolahan stik selain bubur daun singkong yaitu kacang hijau. Kacang hijau merupakan tanaman tropis yang merupakan tanaman kacangkacangan terbanyak ketiga setelah kacang kedelai an kacang tanah.

Berdasarkan data Badan Pusat Statistik (BPS) tahun 2015 produksi kacang hijau di provinsi Riau yaitu sekitar 598 ton. Kacang hijau yang mengandung nutrisi tinggi dapat diolah menjadi bubur kacang hijau, minuman, biskuit, selain itu kacang hijau dapat diolah menjadi tepung yang dapat digunakan dalam pengolahan stik.

Kacang hijau merupakan tanaman yang populer di Indonesia dikarenakan mengandung nutrisi yang tinggi, melihat dari kandungan nutrisi serta warna yang khas pula pada kacang hijau maka dapat di kombinasikan dalam proses pembuatan stik.

Stik kacang hijau daun singkong merupakan jenis makanan ringan yang hampir sama dengan stik lainnya, yang berbahan dasar tepung terigu, dengan bahan tambahan lainnya yaitu, garam,ragi, margarin dan telur. Salah satu faktor dari karakteristik stik kacang hijau daun singkong adalah penambahan bubur daun singkong dan tepung kacang hijau. Selain itu, stik kacang hijau daun singkong ini bisa dijadikan sebagai alternatif baru dalam pengolahan pangan yang tinggi akan nutrisi.

Berdasarkan permasalahan penelitian tersebut, penulis tertarik untuk melakukan penelitian yang berjudul "Pengaruh Penambahan Bubur Daun Singkong terhadap Karakteristik Stik yang Dihasilkan"

\section{Tujuan Penelitian}

Penelitian ini bertujuan untuk 
mengetahui pengaruh penambahan bubur daun singkong terhadap karakteristik stik yang dihasilkan.

\section{Manfaat Penelitian}

Manfaat yang diharapkan dari pelaksanaan penelitian ini adalah :

1. Memberi informasi mengenai proses pembuatan stik kacang hijau dengan penambahan bubur daun singkong.

2. Meningkatkan kuaitas mutu stik kacang hijau dengan dengan menambahkan bubur daun singkong pada produk pengolahannya.

\section{METODOLOGI PENELITIAN}

\section{Bahan}

Bahan utama yang digunakan dalam pembuatan stik adalah tepung kacang hijau dan bubur kulit singkong. Sedangkan bahan tambahan yang digunakan dalam pembuatan stik adalah tepung terigu, telur, air, garam dapur, margarin, ragi instan.

Bahan kimia yang digunakan adalah asam sulfat, air raksa oksida, kalsium sulfat, larutan natrium hidroksida-natrium tiosulfat (larutan 60 g NaOH dan 5 g Na, $\mathrm{S}_{2} \mathrm{O}_{2} 5 \mathrm{H}_{2} \mathrm{O}$ dalam air dan encerkan sampai $100 \mathrm{ml}$ ), larutan asam borat jenuh, larutan asam klorida $0.02 \mathrm{~N}, \mathrm{CaCO}_{3}, \mathrm{~Pb}$-asetat, natrium oksalat dan alkohol $80 \%$.

\section{Alat}

Alat yang produksi yang digunakan antaranya adalah timbangan, ayakan, blender, penggiling mie, mangkok, kompor, alat penggoreng.

Sedangkan alat yang digunakan untuk analisa kimia yaitu pemanas kjeldahl, labu kjeldahl, erlenmeyer 125 $\mathrm{ml}$, buret $25 \mathrm{ml} / 50 \mathrm{ml}$, timbangan analitik, gelas piala $600 \mathrm{ml}$, penangkas air, labu takar $250 \mathrm{ml} / 500 \mathrm{ml}$, kertas whatman No.2, pH-meter, waring belender dan kapas.

\section{Metode Penelitian}

Adapun metode yang digunakan dalam penelitian ini adalah metode experimen langsung yakin mengadakan pengamatan langsung terhadap objek penelitian, dengan berat bahan (bb) yang digunakan adalah 250 gram tepung terigu dan 50 gram tepung kacang hijau. Rancangan yang digunakan adalah rancangan acak lengkap (RAL) dengan perlakuan sebagai berikut.

A : Bubur daun singkong $10 \%$ per bb

B : Bubur daun singkong 20\% per bb

$\mathrm{C}$ : Bubur daun singkong $30 \%$ per bb

D : Bubur daun singkong $40 \%$ per bb

Perlakuan ini diulang sebanyak 4 perlakuan dengan 3 kali ulangan sehingga diperoleh pola perlakuan $4 \times 3$ dengan 12 unit percobaan.

Dari hasil analisis data dilakukan dengan analisis statistik apabila $\mathrm{F}$ hitung $>\mathrm{F}$ tabel (benda nyata) maka dilanjutkan dengan uji BTN (benda nyata kecil) pada taraf nyata $5 \%$.

\section{Pelaksanaan Penelitian}

\section{Proses Pembuatan Tepung Kacang Hijau}

1. Pencucian

Pencucian bertujuan untuk membersihkan kacang hijau dari debu dan memisahkan kacang yang sudah busuk atau rusak.

2. Penjemuran

Penjemuran bertujuan untuk mengeringkan kacang yang sudah dicuci atau dibersihkan, penjemuran ini dilakukan secara alami dengan menggunakan sinar matahari.

3. Penyangraian

Penyangraian dilakuakan dengan suhu $60{ }^{\circ} \mathrm{C}$ selama 3 jam. 


\section{Penggilingan}

Penggilingan ini bertujuan untuk menghaluskan kacang hijau agar mudah untuk dicampurkan dalam pengolahan.

5. Pengayakan

Pengayakan bertujuan untuk menghasilkan tepung kacang hijau yang memiliki tekstur yang lebih halus dan butiran yang seragam. Ayakan yang digunakan berukuran 80-100 mesh.

\section{Proses Pembuatan Bubur Daun Singkong}

1. Pencucian

Pencucian bertujuan untuk membersihkan daun singkong dari kotoran yang tertinggal, debu yang masih menempel serta kotorankotoran yang menempel pada daun singkong.

2. Pengukusan

Pengukusan pada proses pengolahan bubur daun singkong ini sepaya daun singkong empuk dan lembut dan mudah untuk di blender.

3. Penggilingan (blender)

Penggilingan (blender) bertujuan untuk menghaluskan daun singkong, agar mempermudah dalam pencampuran.

\section{Proses Pembuatan Stik}

1. Pencampuran Bahan

Tepung terigu, tepung kacang hijau dan bubur daun singkong dicampurkan sesuai dengan perlakuan, kemudian masing-masing perlakuan ditambahkan 20 gram margarin, 1 butir telur, 1 gram ragi, 60 mil air dan 1 gram garam. Pencampuran dapat dilakukan secara manual yaitu menggunakan tangan sampai membentuk adonan yang homogen, yaitu menggumpal bila dikepal dengan tangan dan tidak lengket didinding wadah yang digunakan.

4. Pengulenan

Adonan yang dibentuk gumpalan, selanjutnya diuleni. Pengulenan ini dapat dilakukan dengan manual, pengulenan dilakukan berulang-ulang sampai adonan kalis (halus).

5. Pembuatan Lembaran

Adonan yang sudah halus di masukan kedalam cetakan mie untuk membuat adonam menjadi lembaran. Adonan di giling berkali-kali senayak tiga kali agar adonan menjadi tipis.

\section{Pencetakan}

Lembaran adonan yang tipis dipotong dengan menggunakan pencetak mie agar lembaran adonan dipotong menjadi panjang dan kecil berbentuk seperti tali.

\section{Penggorengan}

Pengogengan bertujuan agar stik matang, pengorengan dilakukan dengan menggunakan api yang sedang.

8. Penirisan

Setelah stik matang, stik diangkat kemudian ditiriskan. Tujuan pendinginan adalah untuk melepas sisa uap panas pada stik

\section{Pengamatan}

Prameter yang diamati pada penelitian ini adalah uji organoleftik terhadap warna, tektur, aroma dan rasa. Analisa kimia yang diuji yaitu protein dan karbohidrat. 


\section{HASIL DAN PEMBAHASAN}

\section{Kadar Air}

Hasil sidik ragam dari perlakuan penambahan bubur daun singkong dalam pembuatan stik berbeda nyata. Pengaruh penambahan bubur daun singkong terhadap kadar air stik yang dihasilkan setelah uji lanjut dapat dilihat pada tabel 1.

Tabel 1. Rata-rata Analisa Kadar Air terhadap Stik

\begin{tabular}{|c|cc|}
\hline Perlakuan & \multicolumn{2}{|c|}{ Rata-rata (\%) } \\
\hline A (Bubur daun singkong 10\% per bb) & 2,85 & a \\
\hline B (Bubur daun singkong 20\% per bb) & $3,57 \quad$ a \\
\hline D (Bubur daun singkong 40\% per bb) & $4,41 \quad$ a b \\
\hline C (Bubur daun singkong 30\% per bb) & $4,67 \quad$ b \\
\hline
\end{tabular}

Ket: angka-angka pada jalur yang sama diikuti oleh huruf kecil yang sama menunjukkan berbeda tidak nyata menurut Uji Beda Nyata Terkecil pada taraf 5\%

Hasil hasil analisa kadar air menunjukkan bahwa kadar air terendah terdapat pada perlakuan A (Bubur Daun Singkong $10 \%$ ) yaitu sebesar $2,85 \%$ dan perlakuan tertinggi adalah perlakuan $\mathrm{C}$ (Bubur Daun Singkong 30\%) yaitu sebesar $4,67 \%$.

Perlakuan A berbeda tidak nyata dengan perlakuan $\mathrm{B}$ dan $\mathrm{D}$ dan berbeda nyata dengan perlakuan $C$, perlakuan $B$ berbeda tidak nyata dengan perlakuan $\mathrm{A}$ dan $\mathrm{D}$, dan berbeda nyata dengan perlakuan $\mathrm{C}$, perlakuan $\mathrm{C}$ berbeda tidak nyata dengan perlakuan $\mathrm{D}$, dan berbeda nyata dengan perlakuan A dan B, serta perlakuan $D$ berbeda tidak nyata dengan perlakuan A, B dan C.

Rendahnya kadar air pada perlakuan A dikarenakan dalam perlakuan ini sedikitnya penambahan bubur daun singkong, perlakuan A hanya menggunakan bubur daun singkong hanya $10 \%$ per bb, tepung kacang hijau dan tepung terigu. tepung kacang hijau memiliki kadar air yaitu $10 \%$ dan apabila di tambah dengan bubur daun singkong sebesar $40 \%$ maka produk yang dihasilkan akan tinggi kadar air. Kadar air setiap perlakuan berbeda-beda, karena kandungan air dalam bahan pangan dapat dibedakan air terikat dan air bebas.

Penggunaan air yang terlalu banyak akan mengakibatkan adonan menjadi lengket dan sulit ditangani, sedangkan jika terlalu sedikit akan mengakibatkan produk akhir akan menjadi keras. Kandungan air dalam bahan makanan ikut menentukan kesegeran dan daya tahan bahan makanan (Winarno, 1993),

Menurut SNI 01-2886-2006 yaitu tentang kadar air makanan ringan ektrudet maksimal 4\%. Hasil ini menunjukan bahwa kadar air stik perlakuan A dan B yang dihasilkan masih dalam batasan SNI, sedangkan perlakuan $\mathrm{C}$ dan D lebih dari $4 \%$.

\section{Protein}

Hasil sidik ragam dari perlakuan penambahan bubur daun singkong dalam pembuatan stik menunjukan bahwa kadar protein tidak berbeda nyata. Pengaruh penambahan bubur daun singkong terhadap kadar air stik yang dihasilkan setelah uji lanjut dapat dilihat pada Tabel 2. 
Tabel 2. Rata-rata Analisa Protein terhadap Stik

\begin{tabular}{|l|c|}
\hline \multicolumn{1}{|c|}{ Perlakuan } & Rata-rata (\%) \\
\hline C (Bubur daun singkong 30\% per bb) & 6,68 \\
\hline D (Bubur daun singkong 40\% per bb) & 6,94 \\
\hline B (Bubur daun singkong 20\% per bb) & 7,95 \\
\hline A (Bubur daun singkong 10\% per bb) & 8,25 \\
\hline
\end{tabular}

Hasil analisa kadar protein menunjukan bahwa jumlah kadar proten terendah terdapat pada perlakuan $\mathrm{C}$ (Bubur Daun Singkong 30\% per bb) yaitu sebesar $6,68 \%$ dan kadar protein tertinggi terdapat pada perlakuan A (Bubur Daun Singkong 10\% per bb) yaitu sebesar $8,25 \%$. Terigu memiliki kandungan protein yaitu $7,0 \%$, sedangkan tepung kacang hijau mamiliki kandungan protein $19 \%$, dan kandungan gizi daun singkong yaitu $6,2 \%$.

Tepung kacang hijau mengandung sejumlah asam amino essensial yang diperlukan oleh tubuh manusia. Skor asam amino adalah cara menetapkan mutu protein dengan cara mebandingkan kandungan asam amino essensial dalam bahan makanan dengan kandungan asam amino esensial yang sama denggan protein patokan. Asam amino pembatas yang ada pada tepung kacang hijau adalah metionin dan sistein. Sedangkan kandungan asam amino lain sudah memenuhi standar terutama kandungan lisinnya (Sudarminto 2015),

\section{Kadar Pati}

Hasil sidik ragam dari perlakuan penambahan bubur daun singkong dalam pembuatan stik berbeda nyata, pengaruh penambahan bubur daun singkong terhadap kadar air stik yang dihasilkan setelah uji lanjut dapat dilihat pada Tabel 3.

Tabel 3. Rata-rata Analisa Kadar Pati Terhadap Stik

\begin{tabular}{|l|rc|}
\hline Perlakuan & \multicolumn{2}{|c|}{ Rata-rata (\%) } \\
\hline D (Bubur daun singkong 40\% per bb) & 19,39 & a \\
\hline C (Bubur daun singkong 30\% per bb) & 21,20 & a b \\
\hline B (Bubur daun singkong 20\% per bb) & 22,94 & b c \\
\hline A (Bubur daun singkong 10\% per bb) & 24.60 & c \\
\hline
\end{tabular}

Ket : angka-angka pada jalur yang sama diikuti oleh huruf kecil yang sama menunjukkan berbeda tidak nyata menurut Uji Beda Nyata Terkecil pada taraf 5\%

Hasil analisa kadar pati dan C, dan berbeda nyata dengan menunjukan bahwa jumlah kadar pati perlakuan $\mathrm{D}$, perlakuan $\mathrm{C}$ berbeda tidak tertinggi terdapat pada perlakuan $\mathrm{A}$ nyata dengan perlakuan $\mathrm{B}$ dan $\mathrm{D}$, dan (Bubur Daun Singkong 10\%) yaitu berbeda nyata dengan perlakuan A, serta sebesar $24,60 \%$ dan kadar pati terendah perlakuan D berbeda tidak nyata dengan pada perlakuan D (Bubur Daun perlakuan C, dan berbeda nyata dengan Singkong $40 \%$ ) yaitu sebesar 19,39\%.

Perlakuan A berbeda tidak nyata dengan perlakuan $\mathrm{B}$, dan berbeda nyata dengan perlakuan $\mathrm{C}$ dan $\mathrm{D}$, perlakuan $\mathrm{B}$ berbeda tidak nyata dengan perlakuan $\mathrm{A}$ perlakuan A dan B.

Dari data tersebut menunjukkan bahwa semakin besar persentase penambahan bubur daun singkong maka akan semakin kecil pula kandungan 
kadar pati pada stik, sebaliknya semakin sedikit persentase penambahan bubur dauin singkong maka akan semakin tinggi kandungan kadar pati. Menurut Radley (1976), fungsionalitas pati pada produk pangan atu non pangan tergantung dari sifat fisik pati. Sifat fisik pati dipengeruhi oleh dua komponen utama dalam pati yaitu amilosa dan amilopektin. Tingkat pengembangan dan tekstur dari makanan ringan (snack) dipengaruhi oleh resiko dari amilosa dan amilopektin, Tekstur pada produk berbahan dasar pati diperoleh dari hasil perubahan pati selama dan setelah pemasakan. Beberapa faktor yang mempengaruhi tekstur produk antara lain glatinisasi, daya kembang, viscositas dan retrogradasi. Faktor $\mathrm{pH}$ pada pati juga dapat mempengaruhi mutu produk yang berbahan dasar pati.

Kadar pati memiliki peranan penting pada pengembangan produk pangan, baik sebagai bahan baku atau sebagai bahan tambah seperti pengental, penstabil, atau penguat tekstur. Penambahan pati ditunjukan untuk meningkatkan retensi air, mengontrol mobilitas air, dan juga menjaga kualitas produk pangan selama penyimpanan (Pongsawatmanit 2001)

\section{Uji Organoleptik}

\section{Rasa}

Penilaian panelis terhadap rasa stik antara 3,3\%-3,15\%, nilai tertinggi terdapat pada perlakuan D $(40 \%$ bubur daun singkong) yaitu sebesar $3,15 \%$ dan nilai terendah terdapat pada perlakuan $\mathrm{C}$ (30\% bubuhr daun singkong) yaitu sebesar 3,3\%

Rasa merupakan faktor yang juga penting, dari suatu produk makanan. Komponen yang dapat menimbulkan rasa yang diinginkan tergantung dari senyawa penyusunnyaa. Umumnya bahan pangan tidak hanya terdiri dari satu rasa saja akan tetapi dari abungn dari berbgi macam rasa yang terpadu sengga menimbulkan cita rasa yang makanan yang utuh. Cita rasa merupakan akibat integrasi atau saling tindak isyaratyang dihasilkan oleh rangsangan bau, rasa dan iritan dari makanan atau minuman. Persepsi cita rasa biasanya dimulai dengan penilaian visual untuk mengetahui dan menentukan apakah hal itu dapat dimakan atau sebaliknya, (Abdullah 2005)

Rasa memiliki kemampuan mendekteksi yitu rasa menis, asin asam dan pahit. Dalam makanan tertentu empat rasa ini di gabungkan sehingga menjadi suatu rasa yang unik dan menarik untuk dinikmati.

\section{Warna}

Penilaian panelis terhadap warna stik antara 2,55\%-4,25\%, nilai tertinggi terdapat pada perlakuan A $(10 \%$ bubur daun singkong) yaitu sebesar $4,25 \%$ dan nilai terendah terdapat pada perlakuan $\mathrm{C}$ (30\% bubur daun singkong) yaitu sebesar 3,3\%

Semakin tinggi tingkat penambahan bubur daun singkong maka stik yang dihasilkan semakin kecoklatan. hal ini terjadi karena kandungan protein terhadap bahan, yang mana proses pemanasan yang dilakukan menyebabkan terjadinya reaksi Maillard yang mendorong perubahan warna agak kecoklatan terhadap stik, sehingga mengurangi kecerahan pada stik.

Warna merupakan salah satu kriteria dasar untuk menentukan kualitas makanan, antara lain warna dapat memberi petunjuk mengenai perubahan kimia dalam makanan, seperti pencoklatan. Selain itu, beberapa warna spesifik dari buah juga dikaitkan dengan kematangan. Warna juga mempengaruhi 
persepsi akan rasa, oleh karena itu, menimbulkan banyak pengaruh terhadap konsumen dalam memilih produk makanan dan minuman, (Julaiha E, 2014).

\section{Aroma}

Penilaian panelis terhadap rasa stik antara 3,45\%-3,55\%, nilai tertinggi terdapat pada perlakuan B $(20 \%$ bubur daun singkong) yaitu sebesar 3,55\% dan nilai terendah terdapat pada perlakuan $\mathrm{C}$ (30\% bubur daun singkong) yaitu sebesar 3,45\%.

Aroma adalah reaksi dari makanan yang akan mempengaruhi konsumen sebelum konsumen menikmati makanan, konsumen dapat mencium aroma makanan tersebut.

Aroma yang disebarkan oleh makanan merupakan daya tarik yan sangat kuat dan mampu merangsang indera penciuman sehingga membangkitkan selera. Timbulnya aroma makanan disebabkan oleh terbentuknya senyawa yang mudah menguap sebagai akibat atau reaksi karena perkerjaan enzim atau dapat juga terbentuk tanpa bantuan reaksi enzim.

\section{Tekstur}

Penelitian panelis terhadap rasa stik antara 2,90\%-4,05\%, nilai tertinggi terdapat pada perlakuan A $(10 \%$ bubur daun singkong) yaitu sebesar $2,90 \%$ dan nilai terendah terdapat pada perlakuan D (40\% bubur daun singkong) yaitu sebesar 2,90\%.

Ada banyak tekstur makanan antara lain halus atau tidak, cair atau padat, keras atau lembut, kering atau lembab. tingkat tipis halus serta bentuk dan makanan dapat dirasakan lewat tekanan dan gerakan dari reseptor di mulut.

Tekstur adalah salah satu sifat bahan atau produk yang dapat dirasakan melalui sentuhan kulit ataupun pencicipan. Beberapa sifat tekstur dapat juga diperkirakan seperti kehalusan dan kekerasan dari permukaan bahan atau kekentalan cairan. Sedangkan dengan suara atau bunyi dapat diperkirakan tekstur dari kerupuk tekstur dari kerupuk (crisp food). Tekstur produk tergantung pada kekompakan pratikel penyusunannya bila produk tersebut dipatahkan sedangkan mutu teksturnya ditentukan oleh kemudahan perpecahannya praktikel-praktikel penyusunnya bila produk tersebut dikunyah, serta sifatsifat praktikel yang dihasilkan penilaian tekstur suatu bahan melalui mulut dapat dirasakan ketika bahan dipatah atau dikunyah dan ditelan, (Almusawa $\mathrm{M}$ 2013).

\section{KESIMPULAN}

\section{Kesimpulan}

Kesimpulan yang dapat diperoleh setelah melakukan penelitian ini ialah hasil terbaik pada stik yang dihasilkan yaitu perlakuan A dengan penambahan bubur daun singkong sebanyak $10 \%$ per berat tepung kacang hijau dan tepung terigu, yang mempunyai nilai rasa 3,7 , warna 4,25, aroma 3,45, tekstur ,4,05, kandungan air $8,25 \%$, kandungan protein $8,25 \%$ dan kandungan pati $24,60 \%$.

\section{Saran}

Untuk penelitian selanjutnya diharapkan dapat melakukan penelitian dengan mengoptimalkan pemanfaatan daun singkong sebagai bahan baku dengan memperhatikan sifat-sifat fisik dan kimia dari daun singkong itu sendiri sebagai bahan utama dalam pembuatan produk makanan. 


\section{DAFTAR PUSTAKA}

Abdullah A. 2005. Prinsip Penilaian Sensori. [Jurnal] Universitas Kebangsaan Malaysia, UNRI Press. Pekanbaru

Almusawa M. 2013. Penelitian Sensori Pangan Mempelajari Tekstur Makanan. [Jurnal] Program Studiteknologi Industri Pangan. Fakultas Industri Pertanian

Alponsa M. 2015. Ragi Instan, Fungsi dan Cara Pengolahan. http://www. kerjanya.net/2015/09/07/ragi/insta n/fungsi/dan/cara/pengolahannya. (Diakses 07 Januari 2017)

Assosiation Of Official Analytical Chemist. 2005. Offcial Method Of Analysis of The Assosiation Of Official Analytical Chemist. Arlington : The Assosiation Of Official Analytical Chemist, inc

Astawan M. 2008. Membuat Mie Bihun. Penebar Swadaya. Jakarta

Badan Pusat Statistik. 2013. Produksi Buah-buahan dan Sayuran Tahunan di Indonesia, 1995-2013. [Online].http://www.bps.go.id.

(Diakses 27 Januari 2017, jam 20:29WIB).

Buckle AK., Edwards AR., Fleet HG., Wootton M. 2008. Ilmu Pangan. Jakarta : Universitas Indonesia.

Dangkua, S.W. 2013. Karakteristik Organoleptik Dan Kimiawi Produk Stik Rumput Laut (Kappaphycus alvarezii) [Skripsi]. Program Studi Teknologi Hasil Perikanan Jurusan Teknologi Perikanan Fakultas Ilmu-ilmu Pertanian Universitas Negeri Gorontalo. Gorontalo.

Fathia S. 2012. Kandungan dan Manfaat Daun Singkong. http://www. gagaspertanian.com (Diakses 30 Januari 2017)

Julaiha E. 2014. Laporan Praktikum (Analisa Warna).[Jurnal] Program Studi Pendidikan Agroindustri.
Fakultas Pendidikan Dan Kejujuran.Universitas Pendidikan Indonesia

Marhaeniyanto, E. 2007. Pemanfaatan Silase Daun Umbi Kayu untuk Pakan Ternak Kambaing. Buana Sains. Vol.7(1): 71-82

Muhammad F. 2011. Chapter II. Universitas Sumatra Utara. Avalable:http://id.scribd.com//doc/ 54414512/Chapter-II. (Diakses 22 Januari 2017)

Nurbayah, Siti dan Mardesci, Hermiza. 2014. Subtitusi Tepung Terigu dengan Tepung Jagung dan Tepung Ubi Jalar dalam Pengolahan Mie Basah. Jurnal Teknologi Pertanian, Vol.3 No.1, Tahun 2004, p 55-60. ejournal.unisi.ac.id.

Permana S. 2013. 7 Manfaat Daun Singkong.

http://www.shevapermana.com

(Diakses 30 Januari 2017)

Pongsawatmanit, R, P. 2001. Effect Of Sucrose On RVA Viscosity Parameters, Water Activityand Freezable Water Fraction Of Cassave Starch Suspensions. Science Asia 28 : 129-134

Pratiwi F. 2013. Pemanfaatan Tepung Daging Ikan Layang Untuk Pembuatan Stick Ikan. Semarang : Teknologi Jasa dan Produksi. Fakultas Teknik Universitas Negeri Semarang.

Radley JA. 1976. Starch Production Technology. Applied Science Publishers, London.

Rakhmah Y. 2012. Studi Pembuatan Bolu Gulung dari Tepung Ubi Jalar (Ipomoea Batatas L). Universitas Hasanuddin. Makasar. Avalable:

http://repository.unhas.ac.id/bitstre am/handle/123456789/2967/YAU 
MIL\%20RAKHMANAH.pdf?sequ ence $=2$. (Diakses 27 Januari 2017). Retnaningsih C, Hartayani L. 2005. Aplikasi Tepung Iles-iles (Amorphopallus Konjac) sebagai Pengganti Bahan Kimia Pengenyal Pada Mie Basah. Laporan penelitian. Semarang: Teknologi Pangan. Universitas Katolik Soegijapranata.

Salim, Emil. 2011. Mengolah Singkong Menjadi Tepung Mokaf. Lily Publisher, Jakarta

Setiyaning R. 2012. Resep Stik Rayco Renyah. www.dapurnyanafarel. blogspot.com. (Diakses tanggal 13 Januari 2017)

Soekarto. 1985. Penilaian Organoleptik Untuk Psngsn Dan Hasil Pertanian. Dahtara karya Aksara. Jakarta

Sudarmadji S., dkk.2003. analisa Bahan Makanan Dan Pertanian. Kunisius. Yogyakarta.

Sukria, H. A. dan K. Rantan. 2009. Sumber dan Ketersediaan Bahan Baku Pakan di Indonesia. IPB Press, Bogor. 53; 58-61

Winarno FG., Kurwanto. 1992. Kimia Pangan dan Gizi. Jakarta : Gramedia Pustaka

Yuwono SS. 2015. Tepung Kacang Hijau. http://sudorminto.blogspot. com. (Diakses Tanggal 23 Januari 2017)

Zuhry, Ahmad, Mahmudan, Iordbroken. 2010. Proses Pembuatan Mie. 22 Januari 2017
Astri W. 2011. Evaluasi Kemitraan Antara PT. Samudra Jaya Abadi dengan Petani Pembuat Gula Kelapa Mitra di Kabupaten Ciamis. Skipsi. Departemen Agribisnis, Fakultas Ekonomi dan Manajemen, Institut Pertanian Bogor. Bogor.

Badan Pusat Statistik. 2015. Kabupaten Indragiri Hilir dalam Angka.

Arikunto, Suharmisi. 2002. Prosedur Penelitian. Rineka cipta. Jakarta.

Santosa. 2010. Evaluasi Finansial untuk Manager, dengan Software Komputer. Penerbit IPB Press. Bogor.

Kadariah, L. K., dan C. Gray. 1999. Pengantar Evaluasi Proyek. Jakarta: Lembaga Penerbit Fakultas Ekonomi Univesitas Indonesia. Jakarta.

Tohir, Kaslan A. 1991. Seuntai Pengetahuan Tentang Usahatani di Indonesia. Penerbit Bina Aksara, Jakarta.

Hidayat. 2007. Pendidikan masyarakat. CV Pustaka Baca, Surabaya.

Supardi, Dudi. 1993. Memperlajari Faktor-Faktor yang Mempengaruhi Kelunakan Gula Merah dari Nira Kelapa, Studi Kasus di Daerah Cianjur. Skripsi. Fakultas Teknologi Pertanian Institut Pertanian Bogor. Bogor. 